\title{
Is Inward FDI Enhancing or Crowding- out Domestic Innovation Capability in Emerging Markets? Evidence from BRICT Countries
}

\author{
E. Nur Ozkan Gunay \\ Bogazici University, Department of International Trade, Istanbul, Turkey
}

\begin{abstract}
Foreign Direct Investment (FDI) has been considered by many development economists as an important channel for the transfer of technology to emerging markets. However, whether it can promote technological progress for the host country depends on the sector specific and country specific characteristics, especially technological infrastructure and human capital. This study investigates the impact of inward FDI on absorptive capacity and domestic innovation capability in BRICT countries. Two competing hypotheses of the effect of inward FDI are tested by employing panel data approach for BRICT countries for the period of 2000-2007. Empirical results reveal that Random Effects Model outperforms Ordinary Least Square and Fixed Effects Models. The hypothesis that domestic innovation capability stems from knowledge generation process with well equipped human resources like scientists, engineers, technicians, research equipment and cumulative R\&D expenditure is supported for the given sample. Therefore, inward FDI promote domestic firms' innovation capability and the spillover effects may arise through channels such as reverse engineering, skilled labor turnovers, demonstration effects, and backward linkages. In addition, the impact of the effect of local R\&D expenditure on innovation capability is very significant determinant of innovation capability. On the contrary, the hypotheses of crowding-out effect of inward FDI on domestic innovation capability and high welfare and development level in a country stimulates innovation capability is rejected for the BRICT countries.
\end{abstract}

Keywords: FDI, innovation capability, emerging markets, BRICT

\section{Introduction}

The accumulation of knowledge is one of the key determinants for the economic growth of a country. The stock of knowledge can be increased by deliberate investment in Research \& Development (R\&D) capital or diffusion of existing technology. Foreign direct investment (FDI) has been considered by many development economists as an important channel for the transfer of technology to emerging markets, since the inflow of FDI contains knowledge about new technologies and materials, production methods, or organizational management skills. It is suggested that advanced technologies introduced by multinational firms can also diffuse to domestic firms through channels like reverse engineering, skilled labor turnovers, demonstration effects, and backward linkages.

The simple presence of foreign products in domestic markets can encourage local firms' creative thinking and help generate blueprints for new products and processes. As Cheung and Lin (2004) state that, the

Copyright(C 2011 E. Nur Ozkan Gunay. This is an open access article distributed under the Creative Commons Attribution License unported 3.0, which permits unrestricted use, distribution, and reproduction in any medium, provided that original work is properly cited. Contact author: E. Nur Ozkan Gunay e-mail: gunayen@boun.edu.tr 
FDI spillover effect may originate from the foreign firm's finished R\&D projects (their products and technologies) and spillovers to local firms. By observing and analyzing the output of the foreign firm's past $R \& D$ projects, local firms become more effective in conducting their own innovation activity. On the other hand, (Cheung and Lin, 2004) mention crowding-out effect of FDI, arguing that domestic firms may prefer joint ventures with foreign investors as a form of purchasing technologies from abroad and substitute for establishing an innovative environment. The demonstration effect stems from leakage of information about a firm's on-going R\&D activity to its competitors. Such information can benefit the competitors by improving their efficiency in the searching process for innovation.

The primary motivations for developing countries to attract foreign direct investment is to obtain advanced technology from developed countries and then base on this to establish domestic innovation capability. The share of developing countries, especially the emerging markets (EMs) in global FDI inflow has increased substantially in the last decade. In 1995 the developing countries attracted FDI flows around \$116 billion; however in 2008 the amount of FDI inflows attracted by EMs exceeded $\$ 621$ billion. This increase has been a result of the reduction of barriers to FDI, considerable improvements in transportation and communication technologies, and the measures implemented by many governments in EMs to attract FDI.

In the 2000s, FDI has emerged as a very important source of external resource flows to EMs and has become a significant part of capital formation in these countries. However whether FDI can bring positive spillover effect and stimulate technology progress in EMs is controversial. Are there significant spillover effects from inward FDI on R\&D activity of host domestic firms besides financing current account deficit in emerging countries? Do emerging countries simply import technologies without developing their innovative ability? What is the role of cumulative local
R\&D expenditure and local R\&D human resources on innovation capability? This paper examines the spillover effects of FDI and other local factors on innovation capability in BRICT (Brazil, Russian Federation, India, China and Turkey) countries for the period 2000-2007. The empirical evidence support that FDI inflows generate spillover effects on domestic innovation capability; local technological infrastructure and human capital are very important determinants in BRICT countries. On the contrary, the hypothesis of crowding-out effect of FDI on innovation is rejected for the given sample.

A new application from EMs will contribute to the portfolio of emerging economies literature. Therefore, this paper could be of interest to academicians, policy makers and potential investors who are interested in international technology spillovers in BRICT countries.

The rest of paper is organized as follows. Section 2 provides an overview of the pattern of FDI flows in the world and in Turkey Section 3 reviews the existing theoretical and empirical findings regarding the relationship between FDI and factors and policies that attract FDI. Section 4 summarizes the methodology and data. Section 5 presents and discusses the main empirical findings. Concluding remarks are given in the last section, Section 6.

\section{Global Trends in FDI in Emerging Countries: BRICT}

Along fast growth and change in global investment patterns, the definition of FDI has been extended to include a direct acquisition of a foreign firm, construction of a facility, investment in a joint venture or strategic alliance with a local firm with attendant input of technology or licensing of intellectual property.

The global FDI climbed up 26 times from 1985 to 2000 s. FDI inflow was $\$ 1,38$ billion in 2000 whereas it reached record high level, $\$ 1,98$ billion, in 2007 and declined to 1.68 trillion in 2008 due to the recent global crisis (Figure 1). 


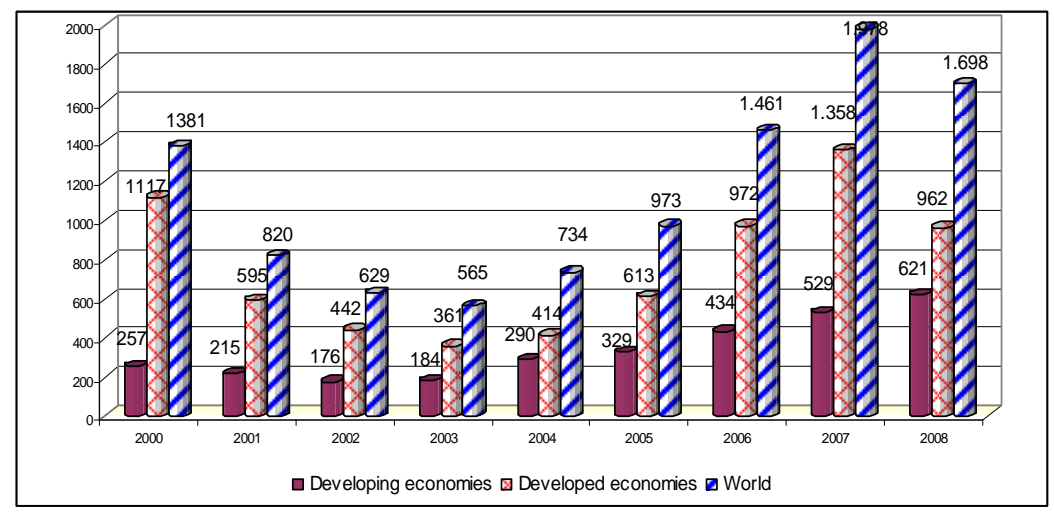

Figure 1: FDI Inflows in the World (\$ billions)

Source: UNCTAD database

FDI inflows to different regions do not follow the same pattern. A parallel trend is observed for the global and developed countries' FDI inflows, however a continous increasing trend is seen for the developing countries. In 2001, world FDI flows dropped due to global slowdown in the world economy and continued to decline for the third year in a row, dropping to $\$ 560$ billion in 2003. Due to the excess global capital injected after 2001 and booming economies all over the world, global FDI inflows started rising after 2003 and approached the record level in 2007. Global FDI inflows rose by $29 \%$ to $\$ 916$ billion in 2005, compared to a $27 \%$ increase in 2004, largely reflecting a significant increase in cross-border M\&As, both in value and in number of deals both in developed and developing countries (WIR, 2006).

After the 1990s, FDI has emerged as a very important source of external resource flows to developing countries and has become a significant part of capital formation in these countries. Developing economies have performed well in recent years, as the global environment has been supportive and they have improved their economic fundamentals by implementation of free market reforms (WIP, 2007). After recovering by $57 \%$ in 2004 , FDI inflows into emerging markets grew by $26 \%$ in 2005 to reach a record high of almost $\$ 400$ billion (more than $40 \%$ of the global total). FDI flows to emerging markets increased by $20 \%$ in 2006 , to $\$ 511$ billion. As noted, the increase of FDI to emerging markets in
2005-06 was weaker than that to developed countries, in part because there had already been a strong emergingmarket recovery in 2004. The negative impact of global financial and economic crisis has affected the FDI flows and it declined by $14 \%$ to $\$ 1,697$ billion in 2008 after the record high level in 2007. FDI flows to emerging markets exceeded $\$ 500$ billion for the first time due to high corporate profits and favorable financing conditions.

Although FDI flows to each part of the world rose, they varied greatly among regions and countries. At the subregional level, developing Asia retained its strong attraction for investors; accounting for more than two thirds of the total inflows to all developing countries in the second half of the 2000s. The increase was due to strong domestic economic growth in key economies, improvements in the investment environment, and regional integration that encourages intraregional investment and facilitates the expansion of production networks by foreign companies. Inflows to Latin America and the Caribbean rose on average by $11 \%$. In West Asia, FDI flows continued their growing trend. Turkey and the oil-rich Gulf States maintained to attract the most FDI inflows, reaching record levels in the second half of the 2000s in spite of geopolitical uncertainty in parts of the region. However, increasing share of BRICT countries in FDI inflows of developing countries is striking (Figure 2). 


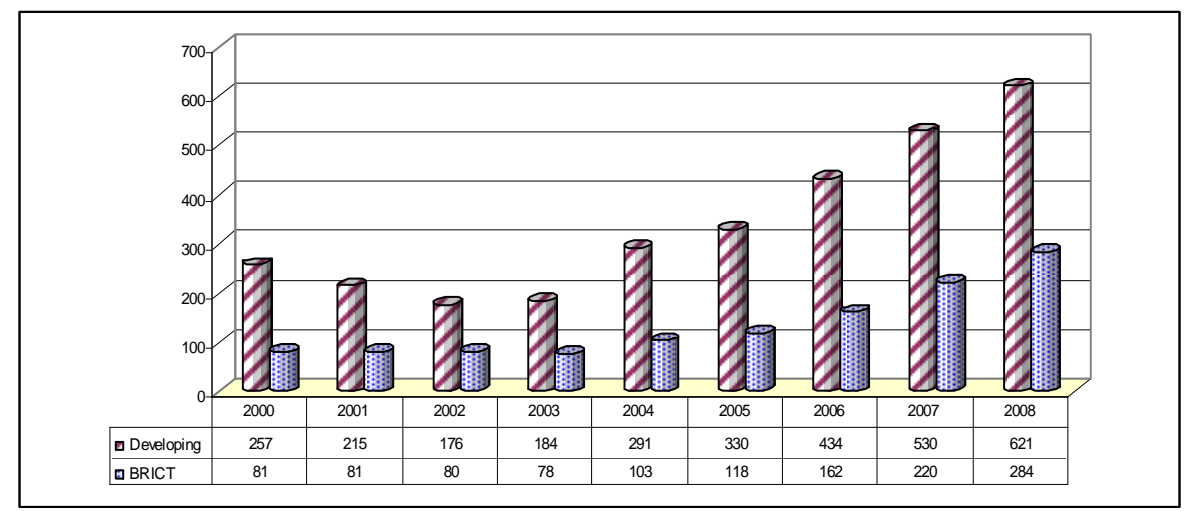

Figure 2: FDI Inflows in Developing and BRICT Economies (US \$ billions) Source: UNCTAD database

The share of BRICT countries in total FDI flows of developing countries has risen from $31 \%$ in 2001 to $46 \%$ in 2008 , whereas their share increased from $6 \%$ to $17 \%$ in global
FDI inflows for the same years. Almost half of the FDI inflows for developing countries originate in BRICT countries.

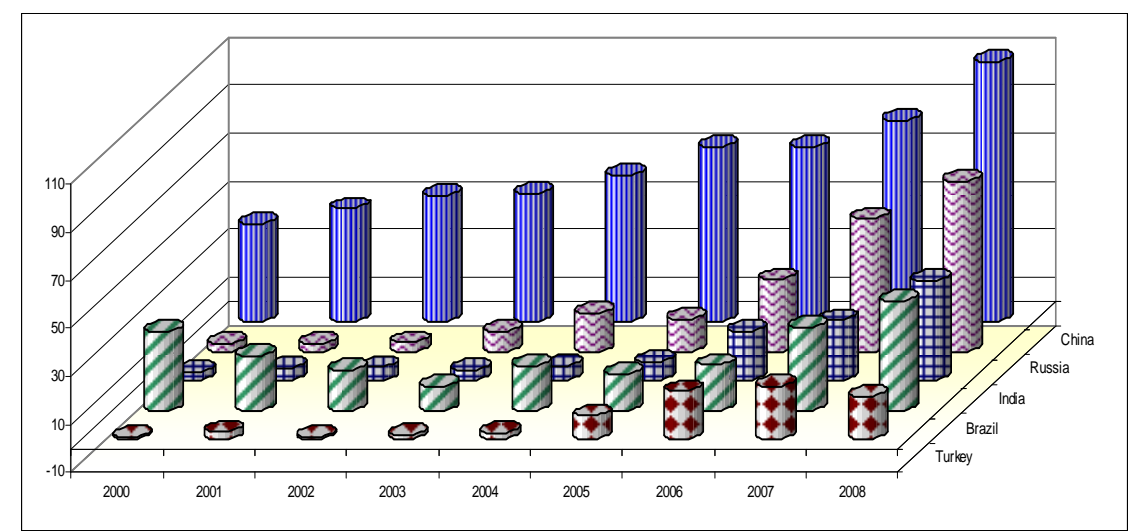

Figure 3: FDI Inflows in BRICT Economies (US \$ billions) Source: UNCTAD database

BRICT countries, China, Brazil, Russia, India and Turkey has accumulated inward FDI inflows $\$ 594$ billion, $\$ 214$ billion $\$ 200$ billion, $\$ 119$ billion and $\$ 80$ billion, respectively for the period of 2000-2008. The accumulation mounts to $\$ 1.2$ trillion in these countries. China is far away the main FDI recipient among emerging markets. China accounted for almost one-fifth of all inflows into emerging markets in 2008. The share of cumulative FDI inflows of China in global cumulative FDI flows is $18 \%$, whereas its share is $40 \%$ in developing countries cumulative inflow. Setting aside the special case of Luxembourg (owing to transshipping), China became the world's largest FDI recipient in 2003, overtaking the United States, traditionally the largest recipient (WIR, 2004).

Hong Kong, China, India, Mexico, Brazil, Singapore and Russia are largest recipients of FDI among developing countries. With a record inflow of $\$ 108$ billion in 2008 , China ranked second globally. According to the UNCTAD survey, India is third in global ranking after China and the US for potential FDI investments during 2009-2011. Moreover, if the share of FDI inflows in GDP is taken into account, India is already 
receiving more inflows than Brazil, China and US. Turkey has a large and dynamic market with a relatively high quality labor force and economic location advantages with easy access to regional markets. Therefore, Turkey has been potentially an attractive country for global investors. Turkey's international direct investment climate has also changed very fast parallel to the development in the global environment in the 2000s and cumulative FDI inflows reached $\$ 70.5$ billion between 2005 and 2008. Following the global crisis, these countries will continue to remain among the top five attractive destinations for international investors during the next two years, according to World Investment Prospects Survey 2009-2011 (UNCTAD).

\section{Literature Review}

International technology spillovers have long been a topic of interest for economists. Grossman and Helpman (1991) identified investment in research and development (R\&D) and international R\&D spillovers as sources of growth in an open economy setting. In the economic literature R\&D plays an important role in at least two different ways. First of all, in the theory of industrial organization and also in the theory of international trade, R\&D is regarded as a strategic variable by which firms capture, or at the least preserve, market shares, and governments give their domestic firms a competitive edge in international trade, either through cost reductions or through product differentiation. Secondly, in growth theory and in the management literature R\&D is thought as an investment in knowledge or in absorptive capacity and hence indirectly as a contributor to economic growth (Mohnen, 1996).

Griliches (1992) determines two main types of R\&D spillovers, which are often confused in the literature: rent spillovers and knowledge (pure) spillovers. International rent spillovers picture the fact that the prices of imported intermediate input and capital goods do not represent completely the product innovation or the quality improvement that result from innovation activities. Therefore, the analysis of productivity growth should take into account the indirect benefits that come up from the technological improvement of goods and services produced by trade partners. Rent spillovers take place when qualities of improvements by a supplier are not fully translated into higher prices for the buyers. Productivity gains are recorded in a different firm or industry than one that generated the productivity gains in the first instance. Rent spillovers emerge in input-output relations. Pure knowledge spillovers cite to the impact of discovered ideas or compounds on the productivity of the research endeavors of others. Pure knowledge spillovers are benefits of innovative activities of one firm that fall to another following market transaction. R\&D enhances the productivity in another sector.

There is considerable empirical evidence concerning positive spillovers arising from FDI. Earliest discussions of spillovers in the literature on FDI date back to the early 1960s. The first author to systematically include spillovers (or external effects) among the possible consequences of FDI was MacDougall (1960), who analyzed the general welfare effects of FDI (Blomström and Kokko, 1997). The contribution of FDI in emerging countries is evident in theory. Emerging countries attract FDI, and then bring technology spillover effects through demonstration, imitation, reverse engineering, individual contact, diffusion of management skills. However, the spillover effects cannot emerge automatically. FDI may also bring negative spillover effects. Because of the stickiness of information, most technology and knowledge are tacit knowledge (von Hopple, 1994). Besides negative effects are also possible due to competition (Aitken and Harrison, 1999).The process and the extent to which spillovers happen were determined by both the owner of the advanced technology (MNCs) and the host countries or local enterprises (Narula and Marin, 2003). The introduction of more advanced technology and the requirement of absorptive capability are critical factors of spillovers (Borensztein et al., 1998). 
For many developing countries, there was no significant relationship between FDI and higher productivity growth in domestic firms, except for those countries having high-level human capital (Borensztein et al., 1998). As China's economic growth has been remarkable since the reform started in 1978, the empirical literature on FDI in China is growing rapidly. Most studies conclude FDI has played a positive role in promoting trade, economic growth. Recently some studies investigate whether FDI generates technology spillover from foreign-investment firms to local ones. There are empirical studies of FDI spillover effects on innovation in China; one of those studies is written by $\mathrm{Hu}$ and Jefferson (2001). They used data for large- and medium sized firms to test the spillover effects of FDI in manufacturing industries in China. They concluded that inward FDI has a positive effect on introduction of new product in china. The other study figured out by Cheung and Lin (2004) is complementary to previous one in that they analyze the provincial data and stress on the geographical aspect of FDI spillovers. Cheung and Lin used provincial data from 1995 to 2000, and they find positive effects of FDI on the number of domestic patent applications in China, they also find that science and technical personnel and expenditure are the most major determinants of innovation output. Both studies indicated that inward FDI to China has promoted R\&D activity by Chinese firms through different spillover channels.

Chen (2007) examined the relationship between FDI and regional innovation capability (RIC) China. The results of that study indicated that the impact of FDI on RIC is weak; the entry of FDI has no use for enhancing indigenous innovation capability. Beside, inward FDI might have the crowding-out effect on innovation and domestic R\&D activity. The research also figures out that increasing domestic $R \& D$ inputs, strengthening the innovation capabilities and absorptive capacity in domestic enterprises are determinant to improve RIC. Liu and Wang (2002) examined the relation between FDI and TFP for Chinese industrial sectors, and they are positive results. Their results indicated that attracting FDI is a significant way of capturing advanced technologies. Ji (2006) tested the spillover effect through import and FDI from the developed countries to China. They found generally significant and positive effect of foreign R\&D stocks through trade and FDI by using provincial data for the periods of 1990 to 2002. So that study empirically supports that both FDI and Import generates externalities in the form of technology transfer. In addition, FDI has larger effect than trade. Furthermore, macroeconomic data is used in the study due to absence of industrial data.

Haddad and Harrison (1991) tested the spillover hypothesis for Moroccan manufacturing during the period 19851989. They conclude that spillovers do not take place in all industrial sectors. They find no significant effects of foreign presence on the rate of productivity growth of local firms. Aitken and Harrison (1991) examined the impact of foreign presence on total factor productivity growth by using plant-level data for Venezuelan manufacturing between 1976 and 1989. They found that domestic firms exhibited higher productivity in sectors with a larger foreign share.

There are not many studies about the spillover effect of FD in Turkey. The studies about FDI in Turkey are generally analyzing the determinant of FDI and the effect of FDI on economic development. Therefore studies about FDI spillovers on technology or innovation are rare. Taymaz and Lenger (2004) study innovation and technology transfer activities of domestic and foreign firms in Turkish manufacturing industries, and the impact of horizontal, vertical and labor spillovers on these activities. Their analyzes indicate that foreign firms are more innovative than their domestic counterparts, transfer technology from abroad, and are likely to establish more co-operative relations for their R\&D activities. According to their research, horizontal spillovers from foreign firms seem to be insignificant, and the effects of foreign firms on technological activities of other firms in vertically related 
industries are ambiguous. Besides, they find that labor turnover is the main channel of spillovers. Finally, they point out that their findings restate the importance of tacitness of knowledge, and confirm that technology cannot be easily transferred through passive mechanism such as demonstration effects or imitation. Another study of Lenger and Taymaz examines the role of multinational companies as the creator and diffuser of new and superior technologies. Their study addresses the question of productivity spillovers from the activity of MNCs, whether the size of recipient firms and the R\&D intensity matter in this respect and do spillovers change by time. They used a longitudinal data for the Turkish manufacturing industry over the 1983-2000 periods. Their results suggest that the spillovers from MNCs for the domestic sector of the Turkish manufacturing industry differentiate with respect to size of the recipient domestic firms and by time. They conclude that the evidence tends to speak in favor negative spillovers in the Turkish manufacturing industry. A new application from emerging markets, BRICT, will contribute to the portfolio of emerging economies literature. Therefore, this paper could be of interest to academicians, practioners, policy makers and regulatory authorities who are interested in energy efficiency.

\section{Methodology and Data}

Based on the theoretical approach presented by the study of Cheung and Lin (2004), the empirical model to analyze the spillover effect of FDI on innovation capability in this study can be rewritten as in equation (1)

$$
I=f(L, K, F D I)
$$

where subscripts $i$ and $t$ denote country and time period, respectively.

The model is modified to estimate the spillover effects of FDI on innovation capability in BRIC countries and Turkey.
$\mathrm{PN}=\beta_{0}+\beta_{1} \mathrm{FDI}_{i t-1}+\beta_{2} \mathrm{R} \& D e x p_{i t}+$

$\beta_{3} \mathrm{R} \& \operatorname{Dper}_{i t}+\beta_{4} \mathrm{GDP}_{i t}+\varepsilon_{i t}$

where subscript $i$ denotes countries and $t$ represents time period.

The variables of the model are as follows:

- PN : The number of patent applications

- FDI-1: The FDI inflow lagged one year

- RDE :The amount of research and development expenditure

- RDP: The number of research and development personnel

\section{- PGDP : Per capita GDP}

The number of patent application, PN, is used as a measure of R\&D output which can be defined as innovation capability in a country. FDI is defined as lagged one period to capture the spillover effect of previous year's FDI inflow. The effect of FDI inflows on patent applications is assumed to be positive due to the assumption that inward FDI brings new technologies and products into the host country and promote domestic firms' innovation capability. R\&D activity in a country depends on the number of personnel employed in R\&D intensive sectors and expenditure on $R \& D$. The $R \& D$ process is essentially a knowledge generation process where resources like scientists, engineers, technicians, research equipment are employed to create new knowledge. Innovation nourishes knowledge that results from cumulative $R \& D$ experience and contributes to this stock of knowledge. The effect of R\&D expenditure and R\&D personnel number on innovation capability is assumed to be positive. The GDP per capita (PGDP) represents welfare and development level in a country. Since the developed countries have more fund ad infrastructure to invest in R\&D, they lead the R\&D activities and have high innovation capability. In order to capture the relationship between innovation 
capability and the level of development in a country, GDP per capita is included as another explanatory variable in the model.

The effect of FDI inflows on innovation in BRICT countries is analyzed by employing Panel Data Models (Green, 1998), Ordinary Least Square (OLS), Fixed Effects Model (FEM) and Random Effects Model (REM) for the period of 2000-2007, during the global pre-crisis period. This period is a new era in FDI inflows especially for the emerging countries.

Since each country is different from each other in terms of economic size and policies, social and political aspects, specific characteristics for each country should also be taken into account. Panel data models takes into account both country specific characteristics and change over the time. Fixed Effect Model (FEM) captures these differences through the intercept term as a means to explicitly allow for individual or time heterogeneity in the temporal cross-sectional data. Thus $\boldsymbol{\alpha}$ is a separate constant term for each unit that varies both cross-sectionally across countries and over timei. The model (Green, 1997) can be specified as:

$\mathrm{Y}_{i t}=\alpha_{i}+\beta / \mathrm{X}_{i t+} \varepsilon_{i t}$

On the other hand, the Random Effect Model (REM) considers the cross section and time series intercepts as random variables. Therefore, the residual have three components indicating what REM considers of time-series errors, crosssection and their interaction.

$\mathrm{V}_{i t}=\alpha_{i}+\lambda_{t}+\mathrm{u}_{i t}$

Where:

- $\alpha_{i}$ is the individual specific component

- $\lambda_{t}$ is time specific component

- $\mathrm{u}_{i t}$ is the normal error term

The generalized regression model of the random effects model where all the disturbances have variance, $\operatorname{Var}\left[\varepsilon_{i t}, \mathrm{u}_{i}\right]$ $=\sigma^{2}=\sigma_{\varepsilon}{ }^{2}+\sigma_{u}{ }^{2}$ can be defined as;

$\mathrm{Y}_{i t}=\alpha_{i}+\beta / \mathrm{X}_{i t+} \varepsilon_{i t}+\mathrm{u}_{i}$

Where:

- $\mathrm{E}[\mathrm{u}]=0$,

- $\operatorname{Var}\left[\mathrm{u}_{i}\right]=\sigma_{u}{ }^{2}$ and $\operatorname{Cov}\left[\varepsilon_{i t}, \mathrm{u}_{i}\right]$

For a given i, the disturbances in different periods are correlated by virtue of their common component,

$\operatorname{Cor}\left[\varepsilon_{i t}+\mathrm{u}_{i}, \varepsilon_{i t}+\mathrm{u}_{i}\right]=\delta=\sigma_{u}{ }^{2} / \sigma^{2}$

NLOGIT (2007) is employed in computing the regression analyses. The data used in the model have been retrieved from different sources for each variable. The data on patent applications as the dependent variable are found from national statistics and World Intellectual Property Organization (WIPO) database. The data covers the period between 2000 and 2007. FDI, R\&D expenditure and personnel statistics is obtained from UNCTAD database.

\section{Empirical Findings and Discussuion}

The econometric models that are utilized in this study are Ordinary Least Squares (OLS), Fixed Effects Model (FEM) and Random Effects Model (REM) to analyze the following hypotheses.

- Hypothesis 1: International technology spillovers through FDI inflows generate spillover effects on domestic innovation capability in BRICT countries.

- Hypothesis 2: Innovation capability stems from knowledge generation process with well equipped human resources like scientists, engineers, technicians, research equipment in BRICT countries.

- Hypothesis 3: Cumulative $R \& D$ expenditure prepares the infrastructure for local innovation capability for the BRICT countries. 
- Hypothesis 4: High welfare and development level stimulates innovation capability in the BRICT countries

Five versions of these models are run separately with different explanatory variables to determine the best identification for innovation capability for the same period. So the sensitivity analysis should also provide an insight for this period empirically. The results of OLS model with different versions are presented in Table 1 for the period of 2000-2007.

Table 1. Ordinary Least Squares Model (OLS)

\begin{tabular}{|c|c|c|c|c|c|}
\hline & Version 1 & Version 2 & Version 3 & Version 4 & Version 5 \\
\hline Independent Variable & Coefficient & Coefficient & Coefficient & Coefficient & Coefficient \\
\hline Constant & $\begin{array}{l}-3220.1 \\
(-0.351)\end{array}$ & $\begin{array}{l}10057.6 \\
(1.418)\end{array}$ & $\begin{array}{c}-17090.16 \\
(-1.797)\end{array}$ & $\begin{array}{c}17693.15^{* *} \\
(2.307)\end{array}$ & $\begin{array}{c}-4308.92 \\
(-1.491)\end{array}$ \\
\hline $\mathrm{FDI}_{\mathrm{t}-1}$ & $\begin{array}{c}0.4651^{* *} \\
(2.088)\end{array}$ & C & $\begin{array}{c}1.4650^{* * *} \\
(7.536)\end{array}$ & $\begin{array}{l}0.1106 \\
(0.480)\end{array}$ & $\begin{array}{c}0.4818^{* *} \\
(2.763)\end{array}$ \\
\hline RDE & $\begin{array}{c}0.8492^{* * *} \\
(6.133)\end{array}$ & $\begin{array}{c}1.0830^{* * *} \\
(12.390)\end{array}$ & 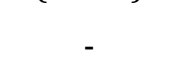 & $\begin{array}{c}1.1448^{* * *} \\
(9.313)\end{array}$ & $\begin{array}{c}0.8426^{* * *} \\
(6.718)\end{array}$ \\
\hline RDP & $\begin{array}{c}0.0212^{* * *} \\
(3.201)\end{array}$ & $\begin{array}{c}0.0143^{* *} \\
(2.321)\end{array}$ & $\begin{array}{c}0.0430 * * * \\
(6.068)\end{array}$ & (- & $\begin{array}{c}0.0217^{* * *} \\
(4.207)\end{array}$ \\
\hline GDPC & $\begin{array}{l}-0.1609 \\
(-0.125)\end{array}$ & $\begin{array}{l}-1.7651 \\
(-1.599)\end{array}$ & $\begin{array}{l}0.8875 \\
(0.644)\end{array}$ & $\begin{array}{c}-2.6427^{* *} \\
(-2.169)\end{array}$ & - \\
\hline $\mathrm{R}^{2}$ & 0.97 & 0.96 & 0.89 & 0.95 & 0.97 \\
\hline Adj. $R^{2}$ & 0.96 & 0.95 & 0.88 & 0.94 & 0.96 \\
\hline $\mathrm{F}[. .]$. & $\begin{array}{l}{[4,21]} \\
145.54\end{array}$ & $\begin{array}{l}{[3,22]} \\
167.08\end{array}$ & $\begin{array}{c}{[3,24]} \\
68.82\end{array}$ & $\begin{array}{l}{[4,22]} \\
134.23\end{array}$ & $\begin{array}{l}{[4,22]} \\
203.13\end{array}$ \\
\hline Log-likelihood & -270.24 & -272.69 & -305.56 & -275.41 & -270.25 \\
\hline
\end{tabular}

The explanatory power of the OLS model $\left(\mathrm{R}^{2}\right.$ and adjusted $\mathrm{R}^{2}$ ) in all versions ranges between $89 \%$ and $96 \%$, indicating a very high explanatory power of the independent variables. However the $\mathrm{R}^{2}$ deteriorates when in the third version when $R \& D$ expenditure is eliminated in the model. The coefficients measure magnitude of the effect coming from explanatory variables on the number of patent applications which is defined as innovation capability. The effect of FDI spillover on patent applications is statistically significant and positive except the fourth version where the R\&D expenditure is ignored. The magnitude of effect FDI spillover on patent applications is large compared to similar studies in the literature and ranges from $46 \%$ to $48 \%$ except the fourth version. A $1 \%$ increase in FDI inflow results in a $46 \%$ increase in the number of patent applications. The magnitude declines when the variable of $R \& D$ expenditure is excluded. Cheng and Lin (2003) find 27\% positive impact of FDI on innovation capability. On the other hand, Chen (2007) finds no significant effect of FDI for the number of patent applications. Expenditure on R\&D seems to be a very important determinant of innovation capability. When this variable is excluded in the model, its impact are reflected to the variables, FDI and $R \& D$ personnel.

The coefficients of R\&D expenditure and personnel are positive and statistically significant even at the $1 \%$ level. Based on the OLS model results, it can be concluded that $R \& D$ expenditure and personnel have very important effects on domestic innovation capability. But the impact of R\&D expenditures on innovation capability is higher than the R\&D personnel. GDP per capita has a negative effect on the number of patent applications in four versions, indicating a negative relationship between 
innovation capability and the level of development in BRICT countries.

The calculated $F$ values in all versions of OLS estimations are higher than the one percent critical value from $F$ Table. Therefore, the hypothesis that the country specific effects are the same is rejected at the one percent level for calculated $\mathrm{F}$ values in Table 1. In this context, FEM and REM are also estimated.

\section{Table 2. Fixed Effects Model (FEM)}

FEM assumes that the intercept changes across countries and for each country there is a constant term. This term captures the country specific characteristics, such as differences in economic and political environment, technological infrastructure and regulations for intellectual property rights. Parallel to the OLS estimation approach, FEM are estimated and the results are presented in Table 2.

\begin{tabular}{|c|c|c|c|c|c|}
\hline & Version 1 & Version 2 & Version 3 & Version 4 & Version 5 \\
\hline Independent Variable & Coefficient & Coefficient & Coefficient & Coefficient & Coefficient \\
\hline $\mathrm{FDI}_{\mathrm{t}-1}$ & $\begin{array}{l}0.2799 \\
(1.022)\end{array}$ & - & $\begin{array}{c}1.3973^{* * *} \\
(5.797)\end{array}$ & $\begin{array}{l}-0.0625 \\
(-0.254)\end{array}$ & $\begin{array}{c}0.5167^{* *} \\
(2.603)\end{array}$ \\
\hline RDE & $\begin{array}{c}0.8787^{* * *} \\
(5.715)\end{array}$ & $\begin{array}{c}1.0028^{* * *} \\
(10.612)\end{array}$ & - & $\begin{array}{c}1.0968^{* * *} \\
(8.600)\end{array}$ & $\begin{array}{c}0.8071^{* * *} \\
(5.579)\end{array}$ \\
\hline RDP & $\begin{array}{c}0.0165^{* *} \\
(2.143)\end{array}$ & $\begin{array}{c}0.0119^{* * * *} \\
(1.901)\end{array}$ & $\begin{array}{c}0.0410^{* * *} \\
(5.038)\end{array}$ & - & $\begin{array}{c}0.0228^{* * *} \\
(3.890)\end{array}$ \\
\hline GDPC & $\begin{array}{l}-2.4441 \\
(-1.233)\end{array}$ & $\begin{array}{c}-3.8644^{* *} \\
(-2.730)\end{array}$ & $\begin{array}{l}-0.0415 \\
(-0.018)\end{array}$ & $\begin{array}{c}-5.2586^{* * *} \\
(-3.202)\end{array}$ & - \\
\hline $\mathrm{R}^{2}$ & 0.97 & 0.97 & 0.90 & 0.96 & 0.97 \\
\hline Adj. $R^{2}$ & 0.95 & 0.95 & 0.85 & 0.94 & 0.95 \\
\hline Est.Autocor. of e(i,t) & 0 & 0 & 0 & 0 & 0 \\
\hline \multirow[t]{2}{*}{$\mathrm{F}[\ldots]$} & {$[10,15]$} & {$[9,16]$} & {$[9,18]$} & {$[9,16]$} & {$[9,16]$} \\
\hline & 51.20 & 56.61 & 19.41 & 46.05 & 54.93 \\
\hline Log-likelihood & -267.62 & -268.50 & -304.04 & -271.09 & -268.88 \\
\hline
\end{tabular}

$\mathrm{R}^{2}$ and adjusted $\mathrm{R}^{2}$ remain almost the same with the OLS model, around 95\%. FEM estimations reveal positive effect of FDI on innovation capability except version 4 . In versions 3 and 5, they are significant. The magnitude of FDI on the number of patent applications seems smaller than the OLS model. It can be interpreted as the spillover effect of the FDI declines when country specific characteristic are take into account. Results represents a similar pattern for other variables when FEM and OLS estimations are compared. OLS and FEM estimations are consistent in terms of $R \& D$ expenditure, personnel and per capita GDP.
The impact of $R \& D$ expenditure and personnel on innovation capability is positive and quite high. When R\&D expenditure is excluded in the model, its impact is captured indirectly. Again, expenditure on R\&D appears to be a very important determinant of innovation capability.

Instead of assuming a set of given constants in FEM, REM merges differential intercepts with the disturbance term. Five versions of estimations for REM are given in Table 3. 
Table 3. Random Effects Model (REM)

\begin{tabular}{lccccc}
\hline & Version 1 & Version 2 & Version 3 & Version 4 & Version 5 \\
& & & & & \\
\hline Independent & Coefficient & Coefficient & Coefficient & Coefficient & Coefficient \\
Variable & & & & & \\
\hline Constant & 652.09 & 10170.01 & $-15843.5^{*}$ & $18083.40^{* *}$ & -4349.84 \\
& $(0.077)$ & $(1.432)$ & $(-1.722)$ & $(2.348)$ & $(-1.613)$ \\
FDIt-1 & $0.4233^{* *}$ & & $1.4513^{* * *}$ & 0.1070 & $0.4923^{* * *}$ \\
& $(2.247)$ & - & $(8.308)$ & $(0.467)$ & $(3.214)$ \\
RDE & $0.8527^{* * *}$ & $1.0823^{* * *}$ & & $1.1430^{* * *}$ & $0.8322^{* * *}$ \\
& $(7.484)$ & $(12.398)$ & - & $(9.343)$ & $(7.522)$ \\
RDP & $0.0200^{* * *}$ & $0.0143^{* *}$ & $0.0426^{* * *}$ & & $0.0220^{* * *}$ \\
& $(3.618)$ & $(2.322)$ & $(6.784)$ & & $(4.858)$ \\
GDPC & -0.7426 & -1.7834 & 0.7080 & $-2.7066^{* *}$ & \\
R & $(-0.631)$ & $(-1.615)$ & $(0.535)$ & $(-2.215)$ & - \\
Var[e] & 0.80 & 0.90 & 0.54 & 0.88 & 0.78 \\
Var[u] & $0.5107 \mathrm{D}+08$ & $0.8878 \mathrm{D}+08$ & $0.1582 \mathrm{D}+09$ & $0.1083 \mathrm{D}+09$ & $0.5625 \mathrm{D}+08$ \\
Corr [v(i, t), v(i, s)] & $0.1140 \mathrm{D}+08$ & $0.3877 \mathrm{D}+08$ & $0.1815 \mathrm{D}+08$ & $0.1461 \mathrm{D}+07$ & $0.6270 \mathrm{D}+07$ \\
LM Test vs. X & 0.1824 & 0.0043 & 0.1028 & 0.0133 & 0.1002 \\
variables[1df,p=0.0] & 1.70 & 0.77 & 1.80 & 0.69 & 1.89 \\
Fixed vs.Random & & & & & \\
Effects (Hausman) & 1.18 & 5.85 & 0.19 & 5.58 & 0.08 \\
\hline
\end{tabular}

*Parameters are statistically different from zero at the $1 \%$ confidence level in a two-tailed $t$ test.

**Parameters are statistically different from zero at the $5 \%$ confidence level in a two-tailed $t$ test.

***Parameters are statistically different from zero at the $10 \%$ confidence level in a two-tailed $t$ test.

$\mathrm{R}^{2}$ ranges between $78 \%$ and $90 \%$ for REM estimations, indicating the strength of variables in explaining the variations in innovation capability. Version 3 is again an exception. The coefficient of FDI variable is positive and significant. In these versions, its impact is around $40 \%$, indicating that a $1 \%$ increase in FDI inflow can lead to $40 \%$ increase in the number of applications. The coefficients of R\&D expenditure, R\&D personnel and GDP per capita variables have similar signs in the OLS and FEM estimations. R\&D expenditure and personnel are very significant while per capita GDP is negative.

The sensitivity analyses for different variables reveal that no improvement is attained when some of the variables are eliminated from the model. Therefore, among different versions of the models, Version 1 can be accepted as the base model. Sensitivity analysis for individual countries is also considered and one country is excluded from the data set in each run. However, the results are very close.

Lagrange Multiplier (LM) test is used to test the performance of REM against OLS with no individual country effects and the Hausman test is used to test the performance FEM against REM. For the base model, LM test results favor REM over OLS model for the period 2000-20007. On the other hand, the Hausman test does not favor FEM against REM.

\section{Conclusion}

Panel data approach is used to determine international technology spillover effect on domestic innovation capability for a group of emerging countries, Brazil, Russia, India, 
China and Turkey (BRICT) for the period of 2000 -2007. Empirical results reveal that REM outperforms OLS and FEM. REM considers the cross section and time series intercepts as random variable and merges differential intercepts with the disturbance term. Therefore, the residual captures country specific, time specific and uncontrolled factors among countries. The coefficient of FDI inflow on domestic innovation capability is always positive for the base model. In addition magnitude of the impact is high and significant for the base model in OLS and REM models. So, the empirical evidence support that FDI inflows generate spillover effects on domestic innovation capability in BRICT. This result supports the hypothesis that inward FDI brings knowledge spillovers, new technologies and products into the host country and promote domestic firms' innovation capability. These spillover effects may arise through channels such as reverse engineering, skilled labor turnovers, demonstration effects, and backward linkages. On the other hand, the hypothesis of crowding-out effect of FDI on innovation is rejected for the given sample.

Explanatory variables, R\&D expenditure and personnel exhibit similar pattern in OLS, FEM and REM for the base model. They are positive and very significant. Therefore, the hypothesis that innovation capability stems from knowledge generation process with well equipped human resources like scientists, engineers, technicians, research equipment and cumulative $R \& D$ expenditure is supported for the given sample. In addition, the impact of the effect of local R\&D expenditure on innovation capability is a very significant determinant of innovation capability. On the contrary, the hypothesis that high welfare and development level in a country stimulates innovation capability is rejected for the BRICT countries.

\section{Acknowledgement}

This study is a part of the project (08N202) supported by Bogazici University Research Fund. The author is grateful for the comments of two anonymous reviewers for IBIMA 2010 Conference on May 26-28, 2010 in Istanbul.

\section{References}

Aitken, B. J. \& Harrison, A. E. (1999). “Do Domestic Firms Benefit from Direct Foreign Investment? Evidence from Venezualla," American Economic Review, 89(3). 605-618.

Blomström, M. \& Kokko, A. (1998). "Multinational Corporations and Spillovers," Journal of Economic Surveys, 12(2). 247-277.

Borensztein, E., De Gregorio, J. \& Lee, J.-W. (1998). "How Does Foreign Direct Investment Affect Economic Growth?," Journal of International Economics, 45(1). 115-135.

Chen, H. \& Chen, T.-J. (1998). "Foreign Direct Investment as a Strategic Linkage," Thunderbird International Business Review, 40(1). 13 - 30.

Greene, W. H. (1997). Econometric Analysis, 3rd edition. Prentice Hall International, New Jersey.

Greene, W. H. (2007). NLOGIT, 4th edition. Econometric Software, Inc., Plainview, NY.

Griliches, Z. (1992). "The Search for R\&D Spillovers," Scandinavian Journal of Economics, 94, 29-48.

Grossman, G. \& Helpman, E. (1991). Innovation and Growth in the Global Economy, MIT Press, Cambridge, MA.

Haddad, M. \& Harrison, A. (1993). "Are There Positive Spillovers from Direct Foreign Investment? Evidence from Panel Data from Morocco," Journal of Development Economics, 42(1). 51-74.

Hu, A. \& Jefferson, G. (2001) FDI, Technology Innovation and Spillover: Evidence from Large and Medium Size Chinese Enterprises, Brandeis University, Waltham, MA, Mimeo.

Ji, M. (2006). "Trade, Foreign Direct Investment and Spillover Effect: An Empirical Analysis on FDI and Import from G7 to China," The International Journal of Economic Policy Studies, 1, 84-97. 
Kui-yin, C. \& Lin, P. (2004). "Spillover Effects of FDI on Innovation in China: Evidence from the Provincial Data?," China Economic Review, 15, 25-44.

Liu, X. \& Wang, C. (2003). "Does Foreign Direct Investment Facilitate Technological Progress: Evidence from Chinese Industries," Research Policy, 32, 945-953.

Mohnen, P. (1996). "R\&D Expenditures and Productivity Growth" STI Review, OECD 18, 39-66.

Narula, R. \& Marin, A. (2003). "FDI Spillovers, Absorptive Capacities and Human Capital Development: Evidence from Argentina," MERIT-Infonomics Research Memorandum series, 2003-2016.

Taymaz, E. \& A. Lenger. (2004). "Multinational Corporations as a Vehicle for Productivity Spillovers in Turkey," Danish Research Unit for Industrial Dynamics Working Paper No. 04-09, 1-16.

UNCTAD. World Investment Reports; 1998, 2004, 2006, 2007, 2008, 2009. United Nations, New York.

UNCTAD. World Investment Prospects; 2007, 2010, 2011. United Nations, New York.

UNCTAD. World Investment Prospects Survey 2009-2011. United Nations, New York.

Von Hipple, E. (1994). "Sticky information and the locus of problem solving: Implications for innovation," Mangement Science, 40, 429-439.

i The problem of multicollinearity is avoided by imposing the following restriction. It assumes that the effects of the numerous omitted individual time varying variables are individually unimportant but are collectively significant where $\varepsilon_{i t}$ is a classical disturbance with $\mathrm{E}\left(\varepsilon_{i t}\right)=0$ and $\operatorname{Var}\left(\varepsilon_{i t}\right)=\sigma_{E}^{2}$ (Greene , 1998). 